\title{
SPATIAL VARIABILITY OF SOME BIOMETRICATTRIBUTES OF SUGARCANE PLANTS (VARIETY IACSP93-3046) AND ITS RELATION TO PHYSICAL AND CHEMICAL SOIL ATTRIBUTES ( $\left.{ }^{1}\right)$
}

\author{
CÉLIA REGINA GREGO $\left({ }^{2 *}\right)$; SIDNEY ROSA VIEIRA $\left({ }^{(3)}\right.$; MAURO ALEXANDRE XAVIER $\left({ }^{4}\right)$
}

\begin{abstract}
Tests to evaluate competition between plants, in general do not consider the soil spatial variability, nevertheless, the uniformity rarely is present and can not be assumed without verification. The aim of this work was to apply geostatistics to verify the spatial variability of the soil in an experimental field near Ribeirão Preto, SP, with sugarcane variety IACSP93-3046. Ninety seven geo-referenced samples, placed at distances of $10 \mathrm{~m}$, were collected for soil chemical analysis, soil resistance to penetration and biometric evaluation of the sugar cane plant included number of tillers, stalk diameter, stalk height, estimated productivity (TSSe) and root density. Geostatistics has been applied by means of semivariogram, data interpolation via kriging and iso-line maps creation. The results have shown soil spatial dependence for most of the evaluated attributes. The spots, within the area, with low resistance to penetration and low soil density have shown the largest number of tillers and the largest root development of sugar cane. For soil chemical attributes, there was spatial dependence showing higher concentration of nutrients in the central area. The sampling allowed a good representativity of the spatial dependence of soil and plants, making it possible to eliminate the randomness hypothesis for the placement of the plots in this area.
\end{abstract}

Key words: Geostatistics, soil chemistry, soil resistance to penetration, root, tillers.

\section{RESUMO \\ VARIABILIDADE ESPACIAL DE ALGUNS ATRIBUTOS BIOMÉTRICOS DAS PLANTAS DE CANA-DE-AÇÚCAR (VARIEDADE IACSP93-3046) E SUA RELAÇÃO COM OS ATRIBUTOS FÍSICOS E QUÍMICOS DO SOLO}

Frequentemente a existência de variabilidade espacial do solo não é considerada, contudo, a uniformidade raramente existe e não pode ser pressuposta sem uma adequada averiguação. O objetivo do trabalho foi utilizar a geoestatística para verificar a variabilidade espacial do solo na área experimental localizada em Ribeirão Preto (SP), sob cultivo da variedade de cana-de-açúcar IAC SP 93-3046. Amostras a cada $10 \mathrm{~m}$, totalizando 97 pontos georreferenciados, foram realizadas para análise química do solo, resistência do solo à penetração e dados biométricos das plantas de cana-de-açúcar incluindo número de perfilhos, diâmetro de colmos, massa de colmos, estimativa de produtividade (TCHe) e densidade de raízes. Utilizouse a análise geoestatística através de semivariogramas, interpolação dos dados por krigagem e construção de mapas de isolinhas. Os resultados evidenciaram dependência espacial para a maioria dos atributos do solo. As manchas na área com menor resistência do solo à penetração e densidade do solo também foram as de maior número de perfilhos e de maior desenvolvimento da raiz da cana-de-açúcar. Para os atributos químicos do solo, houve dependência espacial mostrando maior concentração de nutrientes do solo no centro da área. A amostragem permitiu boa representatividade da dependência espacial do solo e das plantas sendo descartada a hipótese de aleatoriedade para disposição de parcelas nesta área.

Palavras-chave: Geoestatística, química do solo, resistência do solo à penetração, raiz, perfilhos.

(1) Received for publication in September 15, 2008 and accepted in March 18, 2010.

(2) Embrapa Monitoramento por Satélite, Av. Soldado Passarinho, 303, 13070-115 Campinas (SP), Brasil. E-mail:crgrego@cnpm.embrapa.br (*) Corresponding author

( $\left.{ }^{3}\right)$ Centro de Pesquisa e Desenvolvimento de Solos e Recursos Ambientais, IAC, Caixa Postal 28, 13012-970 Campinas (SP). E-mail: sidney@ iac.sp.gov.br

( $\left.{ }^{4}\right)$ Centro Avançado de Pesquisa Tecnológica do Agronegócio de Cana-de-Açúcar, IAC, Caixa Postal 206, 14001-970 Ribeirão Preto (SP). E-mail: mxavier@iac.sp.gov.br 


\section{INTRODUCTION}

The expansion of the sugar and alcohol agricultural activity over the recent years has boosted researches involving sugarcane. Soil physical and chemical attributes that cause adverse impacts to the environment where plants are produced have been intensely investigated in productive areas (ToRMENA et al., 1998; CEDDIA et al., 1999; DiAs Junior et al., 2005; Staut, 2006; SeVEeriano et al., 2007; Silva et al., 2008). Deep, heavy, well-structured, and fertile soils, with good water retention capacity, such as those found in the Northwestern region of the State of São Paulo, are ideal for growing sugarcane (STAUT, 2006), but are also the most susceptible to compaction, which is considered one of the important soil factors that affect productivity. The increasingly higher degree of mechanization in the various stages of the sugarcane production process has strong impact on the soil, reducing its porosity and permeability. The relationship between resistance to penetration and root growth was studied by BRADFORD (1986) and Rosolem et al. (2002); they verified that soil compaction restricted root growth in sugarcane plants, in the resistance to penetration range from $1.34 \mathrm{MPa}$ to 3 $\mathrm{MPa}$ in the various species studied.

Sugarcane (Saccharum spp.) genetic breeding goes through selection stages where the desired phenotypes are sought that will be used later in experimentation conducted in different regions and production environments. At the initial stages, breeders are backed up by some tools and methodologies that enable them to detect individuals with improved commercial value, such as the regional selection method, which allows genotype-environment interactions to be exploited. However, in variety trial areas, it is assumed that the effect of soil variability is not sufficient to modify the soil responses. For this reason, investigation on those areas is still incipient (HoRvat et al., 2006; SiqueIRA et al., 2006). Soil attributes are seldom uniform and this condition cannot be simply assumed without adequate verification. One of the effective ways of investigating soil spatial variability is the use of geostatistical analysis (WARRICK and NIELSEN 1980; GOOVAERTS, 1997; VieIRA 2000, VieIRA et al., 2002, Ortiz et al., 2007; Couto et al., 2007). Geostatistics has many applications in spatial variability studies on agronomic fields, from entomology (DinARDO-MirAnda et al., 2007; FARIAS et al., 2001; 2004; GREGo et al., 2006a) to soil chemical attributes (CAMPBell et al., 1978; VIEIRA, 1997) and soil physical attributes (GREGO et al., 2006b; VIEIRA, 1997), which can provide a vast diversity of data analyses. Consequently, spatial variability investigation can be used to determine regions in the field where the soil is more uniform than others, at the same time answering questions such as:
1.Can a variety trial be installed in a field under the assumption that the responses obtained are due exclusively to the plant's genetic potential?

2.Is it possible to use maps of soil physical and chemical attributes to select sites where plots can be allocated?

The objective of this study was to analyze soil and plant spatial variability of the sugarcane variety IACSP93-3046 in a field where variety trials are conducted.

\section{MATERIAL AND METHODS}

The experimental area is located in Ribeirão Preto, SP, Brazil, on a Eutrophic Red Latosol, according to EMBRAPA (1999). Evaluations were made for sugarcane variety selection fields at the initial stage of plant development by the IAC Sugarcane Research Program, 2002/ 2003 series.

The sampled area was previously cultivated with Crotalaria juncea L. in December 2005 without any applications of fertilizers and $\mathrm{pH}$-correcting materials, using a mechanical seeder. The seeds were planted in rows at a density of $15 \mathrm{~kg}$ of seeds per hectare. Soil tillage was performed under the conventional system. Sugarcane was planted in succession to Crotalaria juncea L. in a one-hectare portion of the area.

The sampling points were placed using the direction of contour farming as a reference, and resulted in a field measuring $50 \mathrm{~m}$ width by $370 \mathrm{~m}$ length.

Soil resistance to penetration measurements were made using an impact penetrometer at a $0.0-0.40 \mathrm{~m}$ depth, according to STOLF (1991), in 205 sampling points arranged in a $10 \times 10 \mathrm{~m}$ grid, according to Figure $1 \mathrm{a}$. Since those were the initial measurements, they served as basis to place the sampling area for all others. A mean soil water content of $17.7 \%$ was obtained at the time resistance to penetration was measured. Bulk density was obtained at $0.0-0.2 \mathrm{~m}$ and at $0.2-0.4 \mathrm{~m}$ depths by undisturbed soil sample using the volumetric ring method described by CAMARGO et al. (1986). The soil chemical attributes were determined following the methodology of RAIJ et al. (2001), but could be sampled only at $0.0-0.20 \mathrm{~m}$, at 97 sampling points arranged on a $10 \times 10 \mathrm{~m}$ grid, as shown in Figure 1b, i.e., on the upper part of the sampling area for resistance to penetration. This portion of the area was considered in order to observe the variability of other soil and plant attributes because it showed a different behavior characterized by resistance to penetration.

A sugarcane variety, IACSP93-3046, was grown, which is characterized by a robust, responsive growth profile (LANDELL et al., 2005), which facilitates phenotype 
expression according to differences that each point may present. Sugarcane crop evaluations were made at 97 sampling points. The plant characteristics recorded included number of tillers per linear meter; stalk diameter, stalk height, and estimated productivity (TSSe), according to the method described by MARTINS and LANDELL (1995). Root density was determined based on the monolith method as described by VASCONCELOS et al. (2002).

The data were submitted to exploratory statistical analysis, with determinations of mean, variance, standard deviation, coefficient of variation, minimum and maximum values, amplitude, asymmetry and kurtosis, using the STAT software presented by VIEIRA et al. (2002). Geostatistical tools were used to determine data spatial variability by means of semivariograms, as demonstrated by VIEIRA (2000). Once the spatial variability of the attributes was detected with a semivariogram, it was possible to calculate values for non-sampled sites, using the kriging interpolation technique. Unbiased interpolation for non-sampled sites with minimum variance allowed the construction of isoline maps for the attributes involved in this study using the SURFER 7.0 (GOLDEN SOFTwARE, 1999).

\section{RESULTS AND DISCUSSION}

The statistical parameters for the variables analyzed are presented in table 1 . The parameters for soil physical variables indicated high variation in resistance to penetration data, with coefficients of variation ranging from $32.9 \%$ to $79.8 \%$, which reflects a wide range between maximum and minimum values. According to the criterion established by WARRICK and NIELSEN (1980), coefficient of variation values are classified as low $<12.0$ $\%$, medium from $12.0 \%$ to $60.0 \%$, and high $>60.0 \%$. The coefficients of asymmetry and kurtosis found are near zero and three, respectively, which, according to WEBSTER and Oliver (2001), identify a normal distribution. However, the statistic software used STAT, developed by VIEIRA et al. (2002), standardizes kurtosis results as zero (0); therefore, in this work, kurtosis values near zero mean that the distribution is considered to be normal, differently from the soil physical attributes results in Table 1. According to SouzA et al. (2004), data normality is not a requirement in geostatistics. More important than data normality is the occurrence of a proportional effect where the mean and the variance of data are not constant in the study area.

Table 1. Statistical parameters of soil chemical and physical attributes and biometric data of the sugar cane plant

\begin{tabular}{|c|c|c|c|c|c|c|c|c|c|c|}
\hline Name & Unit & Num & Mean & Variance & Std.Dev. & C.V. & Minimum & Maximum & Skewness & Kurtosis \\
\hline \multicolumn{11}{|c|}{ Soil physical attributes } \\
\hline Impact number & & 202 & 25.00 & 66.850 & 8.176 & 33 & 11.00 & 52.00 & 0.679 & -0.023 \\
\hline $\mathrm{RP} 0-0.05 \mathrm{~m}$ & $\mathrm{MPa}$ & 202 & 1.69 & 1.823 & 1.350 & 80 & 0.16 & 6.69 & 1.299 & 1.430 \\
\hline $\mathrm{RP} 0.05-0.10 \mathrm{~m}$ & $\mathrm{MPa}$ & 202 & 2.61 & 2.042 & 1.429 & 55 & 0.09 & 9.95 & 1.991 & 6.619 \\
\hline $\mathrm{RP} 0.10-0.15 \mathrm{~m}$ & MPa & 202 & 3.18 & 2.194 & 1.481 & 45 & 0.09 & 9.61 & 1.512 & 3.676 \\
\hline $\mathrm{RP} 0.15-0.20 \mathrm{~m}$ & MPa & 202 & 3.16 & 2.066 & 1.437 & 45 & 0.09 & 8.57 & 1.260 & 2.410 \\
\hline $\mathrm{RP} 0.20-0.25 \mathrm{~m}$ & MPa & 202 & 3.17 & 2.033 & 1.426 & 45 & 0.09 & 8.34 & 1.292 & 2.400 \\
\hline $\mathrm{RP} 0.25-0.30 \mathrm{~m}$ & $\mathrm{MPa}$ & 202 & 2.86 & 1.704 & 1.305 & 46 & 1.03 & 9.61 & 2.002 & 6.823 \\
\hline $\mathrm{RP} 0.30-0.35 \mathrm{~m}$ & $\mathrm{MPa}$ & 202 & 2.84 & 1.084 & 1.041 & 37 & 0.85 & 6.50 & 0.625 & 0.734 \\
\hline $\mathrm{RP} 0.35-0.40 \mathrm{~m}$ & $\mathrm{MPa}$ & 202 & 1.73 & 0.993 & 0.996 & 58 & 0.19 & 5.81 & 0.705 & 0.771 \\
\hline$P$ (bulk density) $0.0-0.20 \mathrm{~m}$ & $\mathrm{~kg} \cdot \mathrm{m}^{-3}$ & 97 & 1.36 & 0.005 & 0.068 & 5 & 1.19 & 1.48 & -0.359 & -0.288 \\
\hline$P$ (bulk density) $0.20-0.40 \mathrm{~m}$ & $\mathrm{~kg} \cdot \mathrm{m}^{-3}$ & 95 & 1.35 & 0.004 & 0.066 & 4 & 1.20 & 1.50 & -0.001 & -0.472 \\
\hline \multicolumn{11}{|c|}{ Soil chemical attributes $(0.0-0.20 \mathrm{~m})$} \\
\hline $\mathrm{pH}$ & admensional & 97 & 5.20 & 0.034 & 0.184 & 3 & 4.80 & 5.70 & 0.217 & -0.402 \\
\hline S.O.M & $\mathrm{g} \mathrm{dm}^{-3}$ & 97 & 26.80 & 11.440 & 3.382 & 13 & 20.00 & 35.00 & 0.289 & -0.576 \\
\hline $\mathrm{P}$ & $\mathrm{mg} \mathrm{dm} \mathrm{d}^{-3}$ & 97 & 25.20 & 63.450 & 7.966 & 31 & 15.00 & 51.00 & 0.954 & 0.209 \\
\hline $\mathrm{K}^{+}$ & $\mathrm{mmol}_{\mathrm{c}} \mathrm{dm}^{-3}$ & 97 & 1.90 & 0.530 & 0.728 & 38 & 0.70 & 5.10 & 1.245 & 2.830 \\
\hline $\mathrm{Ca}^{2+}$ & $\mathrm{mmol}_{\mathrm{c}} \mathrm{dm}^{-3}$ & 97 & 24.50 & 17.600 & 4.196 & 17 & 16.00 & 37.00 & 0.382 & 0.072 \\
\hline $\mathrm{Mg}^{2+}$ & $\mathrm{mmol}_{\mathrm{c}} \mathrm{dm}^{-3}$ & 97 & 9.30 & 6.410 & 2.531 & 27 & 5.00 & 16.00 & 0.404 & -0.601 \\
\hline $\mathrm{H}+\mathrm{Al}^{3+}$ & $\mathrm{mmol}_{\mathrm{c}} \mathrm{dm}^{-3}$ & 97 & 36.30 & 42.390 & 6.511 & 18 & 22.00 & 55.00 & 0.465 & 0.570 \\
\hline $\mathrm{V}$ & $\%$ & 97 & 49.00 & 57.960 & 7.613 & 15 & 33.00 & 68.00 & 0.227 & -0.378 \\
\hline \multicolumn{11}{|c|}{ Biometric data of sugar cane plant } \\
\hline Tillers & Tillers $\mathrm{m}^{-1}$ & 97 & 13.54 & 1.230 & 1.110 & 8 & 11.000 & 17.11 & 0.494 & 0.876 \\
\hline Stalk diameter & $\mathrm{cm}$ & 95 & 2.73 & 0.020 & 0.150 & 5 & 2.350 & 3.10 & -0.040 & -0.010 \\
\hline Stalk height & $\mathrm{cm}$ & 97 & 184.50 & 191.900 & 13.850 & 7 & 160.000 & 220.00 & 0.160 & -0.496 \\
\hline TSSe & ton & 97 & 97.71 & 202.600 & 14.230 & 14 & 71.980 & 136.50 & 0.384 & -0.616 \\
\hline$P$ (bulk density) $0.0-0.20 \mathrm{~m}$ & $\mathrm{~kg} \cdot \mathrm{m}^{-3}$ & 95 & 32.53 & 95.350 & 9.765 & 30 & 12.500 & 57.80 & 0.241 & -0.330 \\
\hline$P$ (bulk density) $0.20-0.40 \mathrm{~m}$ & $\mathrm{~kg} \cdot \mathrm{m}^{-3}$ & 96 & 16.98 & 59.400 & 7.707 & 45 & 3.500 & 39.20 & 0.872 & 0.391 \\
\hline
\end{tabular}


This sampling was performed in 205 points and, because of the wide variation obtained, it was decided to adopt a portion of the area that showed typical resistance to penetration variation at short distances for the other samplings. This criterion was used to pre-define the area where the sugarcane variety under selection should be planted, as well as the other variables that were sampled in 97 points. The analysis results for bulk density data (Table 1) showed much smaller coefficients of variation (5.0\% and $4.9 \%)$ than for resistance to penetration, with normal distribution. Bulk density values through the soil depth did not show great variations either. SEVERIANO et al (2007) found high susceptibility to compaction on a Dark Red Dystrophic Latosol (LVd), with a bulk density value critical for sugarcane development of $1.7 \mathrm{~kg} \mathrm{~m}^{-3}$, which was considered by the authors as an indication that crop development would be restricted.

Low to medium coefficient of variation values were obtained for the chemical analysis (Table 1). The lowest coefficient of variation $(3.5 \%)$ was obtained for $\mathrm{pH}$, with low variation according to the classification proposed by WARRICK and NiELSEN (1980). A similar result was found by SouzA et al. (2004) at the same sampling depth (0.0-0.2 m). Asymmetry and kurtosis values were near zero, identifying a normal distribution. The mean of base saturation was approximately $50.0 \%$, ranging from low (33.0\%) to high values $(68.0 \%)$. According to Staut (2006), sugarcane stands with low base saturation values (around 30.0\%) restrict root development and consequently crop productivity. The mean value found for $\mathrm{pH}$ (5.2) is not considered restrictive for crop development, considering that sugarcane has good tolerance and adaptability to soil acidity. Rosseto et al. (2004) studied the liming effect and potassium fertilization in sugarcane areas of the State of São Paulo and identified responses to liming only in soils with $\mathrm{pH}$ values lower than 4.4. In general, no soil fertility problems were found, with medium to high macronutrient values.

The plant biometric data showed low variation, with CV (\%) values from low to medium according to WARRICK and NIELSEN (1980), and normal distribution

Table 2. Parameters of semivariograms, nugget $\mathrm{Co}$, sill $\mathrm{C} 1$, range of spatial dependence $a$ (m), correlation coefficient $\mathrm{r}^{2}$ and the degree of space dependence DD $(\%)$

\begin{tabular}{|c|c|c|c|c|c|c|}
\hline Name & Model & $\mathrm{Co}$ & $\mathrm{C} 1$ & $\mathrm{a}(\mathrm{m})$ & $\mathrm{r}^{2}$ & $\mathrm{DD}$ \\
\hline \multicolumn{7}{|c|}{ Soil physical attributes } \\
\hline Impact Number & Spherical & 40.00 & 35.00 & 55.00 & 0.194 & 46.67 \\
\hline $\mathrm{RP} 0-0.05 \mathrm{~m}$ & Spherical & 1.40 & 0.49 & 24.81 & 0.047 & 25.93 \\
\hline $\mathrm{RP} 0.05-0.10 \mathrm{~m}$ & Spherical & 1.50 & 0.70 & 45.00 & 0.042 & 31.82 \\
\hline RP $0.10-0.15 \mathrm{~m}$ & Spherical & 1.70 & 0.70 & 40.00 & 0.128 & 29.17 \\
\hline $\mathrm{RP} 0.15-0.20 \mathrm{~m}$ & Spherical & 1.60 & 0.70 & 60.00 & 0.056 & 30.44 \\
\hline $\mathrm{RP} 0.20-0.25 \mathrm{~m}$ & Spherical & 1.60 & 0.55 & 55.00 & -0.079 & 25.58 \\
\hline $\mathrm{RP} 0.25-0.30 \mathrm{~m}$ & Spherical & 1.40 & 0.40 & 50.00 & -0.060 & 22.22 \\
\hline $\mathrm{RP} 0.30-0.35 \mathrm{~m}$ & Spherical & 0.85 & 0.20 & 30.00 & -0.071 & 19.05 \\
\hline $\mathrm{RP} 0.35-0.40 \mathrm{~m}$ & Spherical & 0.70 & 0.30 & 20.00 & -0.018 & 30.00 \\
\hline$p$ (bulk density) $0.0-0.20 \mathrm{~m}$ & Spherical* & 0.003 & 0.001 & 50.00 & 0.301 & 25.00 \\
\hline$p$ (bulk density) $0.20-0.40 \mathrm{~m}$ & Spherical* & 0.003 & 0.001 & 20.00 & 0.006 & 25.00 \\
\hline \multicolumn{7}{|c|}{ Soil chemical attributes $(0.0-0.20 \mathrm{~m})$} \\
\hline $\mathrm{PH}$ & Spherical & 0.03 & 0.01 & 50.00 & -1.761 & 25.00 \\
\hline S.O.M. & Spherical & 2.15 & 9.50 & 39.80 & 0.507 & 81.55 \\
\hline $\mathrm{P}$ & Spherical & 25.00 & 38.00 & 21.46 & 0.144 & 60.32 \\
\hline $\mathrm{K}^{+}$ & Gaussiano & 0.40 & 0.18 & 56.51 & 0.911 & 31.03 \\
\hline $\mathrm{Ca}^{2+}$ & Spherical & 10.30 & 9.81 & 76.19 & 0.796 & 48.78 \\
\hline $\mathrm{Mg}^{2+}$ & Spherical & 5.05 & 1.71 & 76.59 & 0.659 & 25.30 \\
\hline $\mathrm{H}+\mathrm{Al}^{3+}$ & Spherical & 28.74 & 13.93 & 21.46 & 0.196 & 32.65 \\
\hline $\mathrm{V} \%$ & Spherical & 45.82 & 18.27 & 89.20 & 0.893 & 28.51 \\
\hline \multicolumn{7}{|c|}{ Biometric data of sugar cane plant } \\
\hline Tillers & Spherical & 0.95 & 0.22 & 45.00 & 0.086 & 18.80 \\
\hline Stalk diameter & Spherical $* *$ & 0.01 & 0.01 & 60.00 & -0.275 & 31.43 \\
\hline Stalk height & Spherical & 110.00 & 98.00 & 75.00 & 0.576 & 47.12 \\
\hline TSSe & Spherical & 170.00 & 30.00 & 45.00 & 0.132 & 15.00 \\
\hline Root density $0.0-0.20 \mathrm{~m}$ & Spherical & 80.00 & 24.00 & 40.00 & 0.094 & 23.08 \\
\hline Root density $0.20-0.40 \mathrm{~m}$ & Spherical & 33.00 & 29.00 & 40.00 & 0.360 & 46.77 \\
\hline
\end{tabular}

* Tendency residual linear. ${ }^{* *}$ Tendency residual parabolic. 
with asymmetry and kurtosis values near 0 . Mean values found for sugar cane yield are considered to be high (values above $70.0 \mathrm{t} \mathrm{ha}^{-1}$ ) according to STAUT (2006). Based on mean sugarcane root density, it can be noted that their values decreased by approximately $47.8 \%$ in the $0.20-0.40 \mathrm{~m}$ depth layer, showing higher concentration of roots in the soil surface layer, followed by a reduction of the space occupied by them in the $0.20-0.40 \mathrm{~m}$ depth layer. This probably occurred because the surface layer provided the best conditions for root development, such as fertility and soil moisture, in addition to the fact that the evaluation was based on first year cane, in which ratoon tillering is only beginning, therefore with more superficial plants. No pattern can be found in the literature (MACHADO, 1987, BALLCoelho et al., 1992, VAsconcelos and Casagrande, 2008) for sugarcane root system distribution in depth, since such distribution is intimately associated with several factors such as genotype, plant age, soil physical and chemical conditions, and water availability. According to Vasconcelos and CASAgrande (2008), the first year cane root system exploits the more superficial layers more intensely when compared with ratoon cane, with increased subsurface exploitation in the latter, in agreement with the root density reduction from the surface to the subsurface observed in Table 1.

The semivariograms for the attributes in this study that showed spatial dependence by fitting a predominantly spherical model are presented in Figures $1,2,3$, and 4 . Table 2 shows the fitting parameters for the semivariograms. With respect to resistance to penetration and plant biometric data, spatial Dependency Degree values (DD \%) ranged from low to moderate, according to classification ZІмBACK (2001). Soil chemical attributes, however, had high DD percentages (up to 81.5\%). This indicates variability both in the area containing 205 points and in the area with 97 points. The range values that represent the size of existing patches for the variables

(a)

(b)
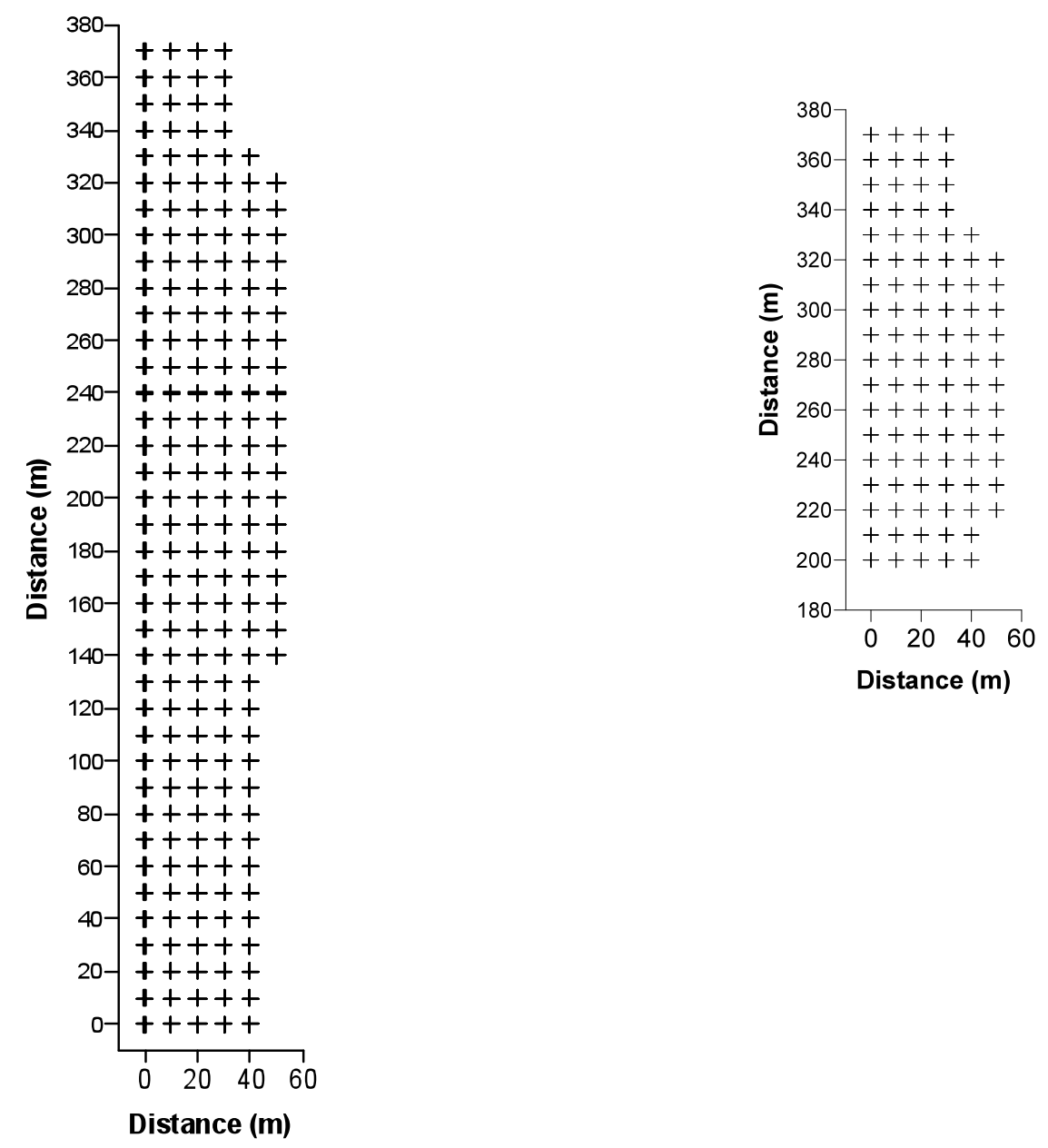

Figure 1. Sampling grids: a) 205 points for resistance of soil penetration; b) 97 points for soil density, chemical analysis and variable sugarcane plants. 
evaluated varied from 20 to 55 meters for physical attributes, 21.5 to 89.2 meters for chemical attributes, and 40.0 to 75.0 meters for data associated with sugarcane plants. The smaller range values obtained for soil physical attributes data reveal a large number of discrepant values in neighboring samples especially for resistance to penetration, which also showed low structural variance (C1) and high nugget effect values (Co). (a)

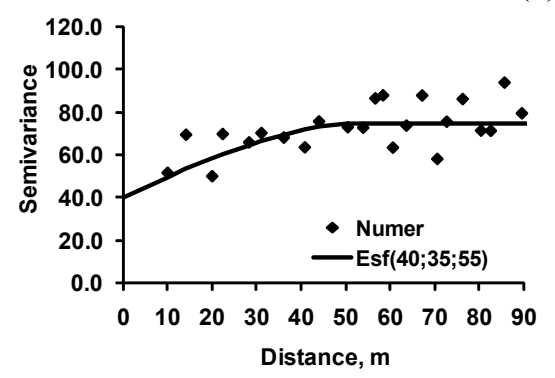

(d)

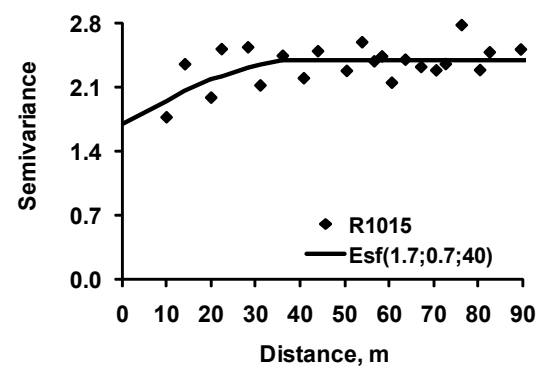

$(\mathrm{g})$

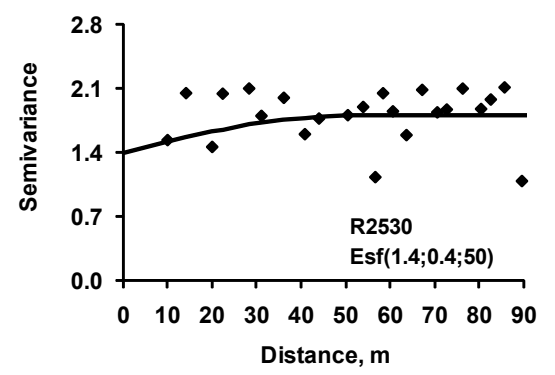

(b)

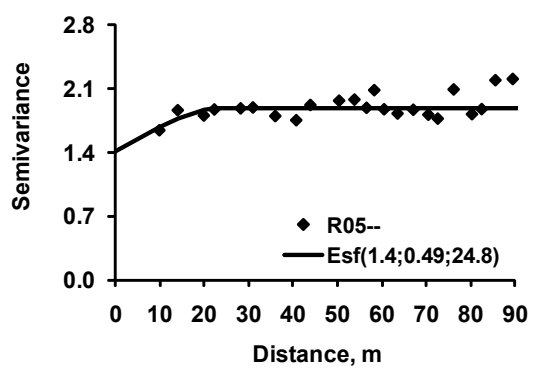

(e)

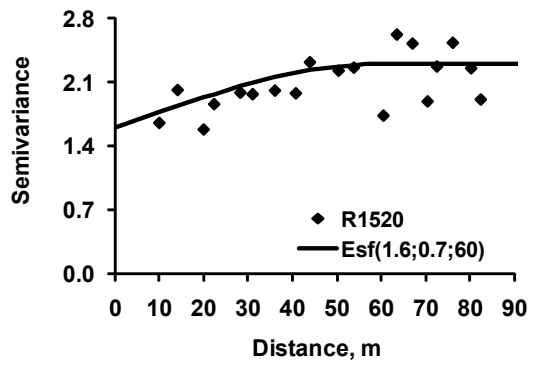

(h)

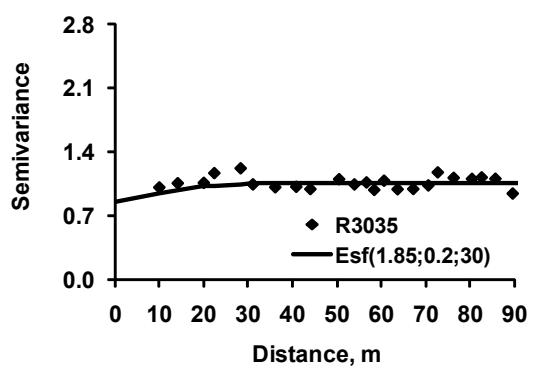

(c)

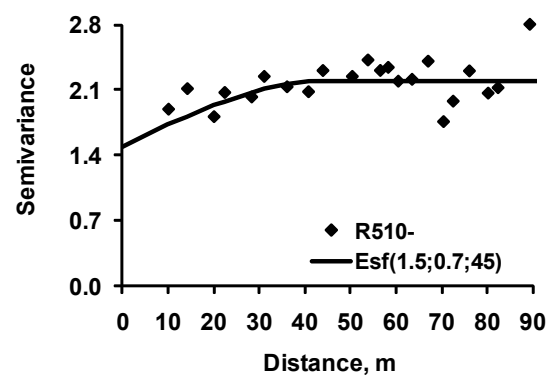

(f)

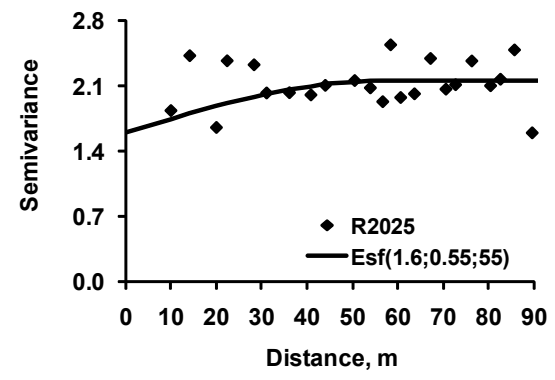

(i)

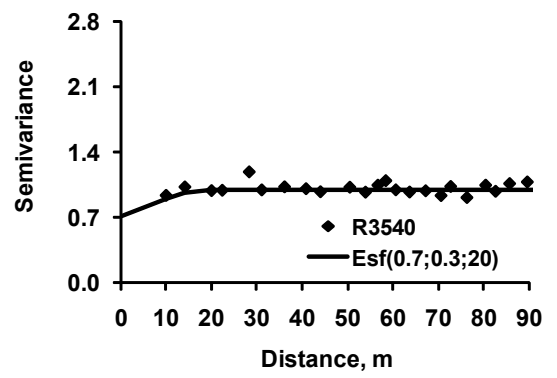

(j)
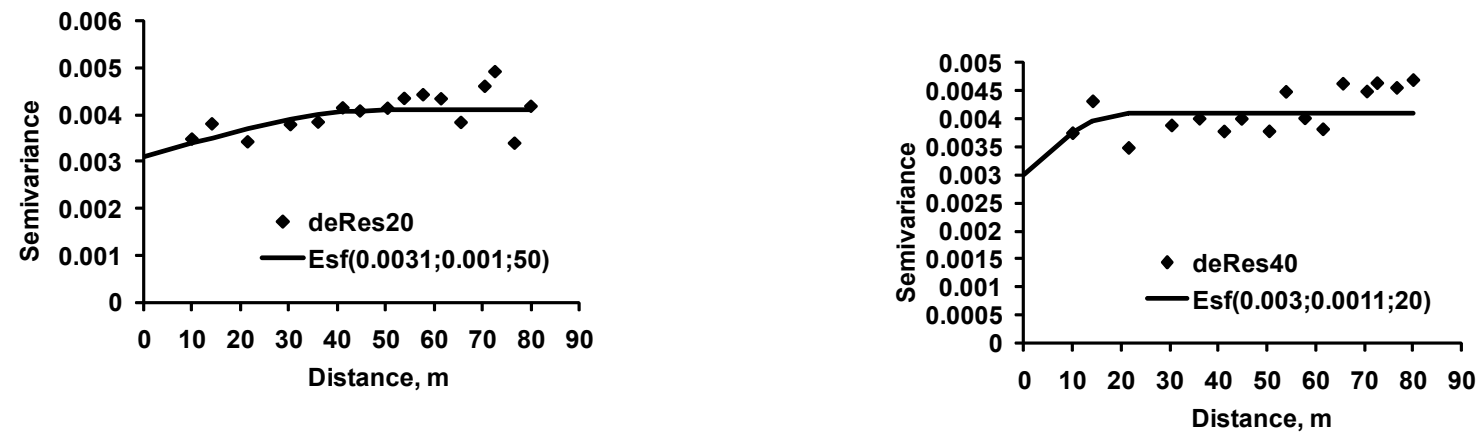

Figure 2. Semivariograms for resistance soil penetration 0.0 a $0.40 \mathrm{~m}$ of depth: a) Strokes number; $\mathrm{b}$ ) Resistance $\mathrm{kPa} 0-0.05 \mathrm{~m}$; c) Resistance $\mathrm{kPa}$ 0.05-0.10 m; d) Resistance kPa 0.10-0.15 m; e) Resistance kPa 0.15-0.20 m; f) Resistance kPa 0.20-0.25 m; g) Resistance kPa 0.25-0.30 m; h) Resistance kPa 0.30-0.35 m; i) Resistance kPa 0.35-0.40 m, j) soil density 0.0-0.20 m; k) soil density $0.20-0.40 \mathrm{~m}$. Semivariograms for soil density : j) 0.0-0.20 $\mathrm{m}$ of the depth; k) $0.2-0.40 \mathrm{~m}$ of the depth. 
(a)
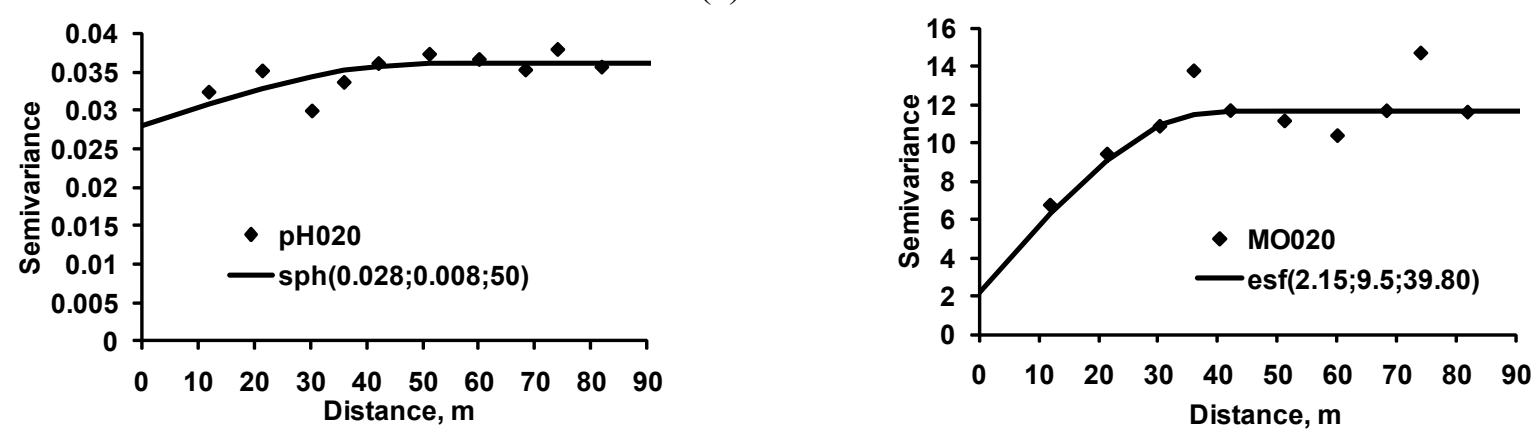

(b)

(c)
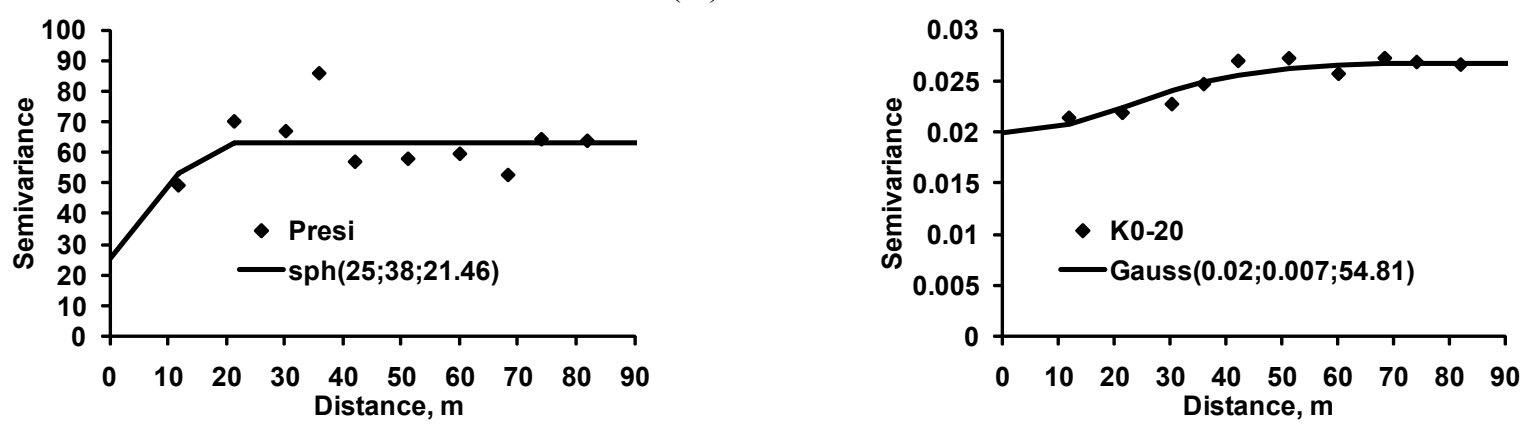

(d)

(e)
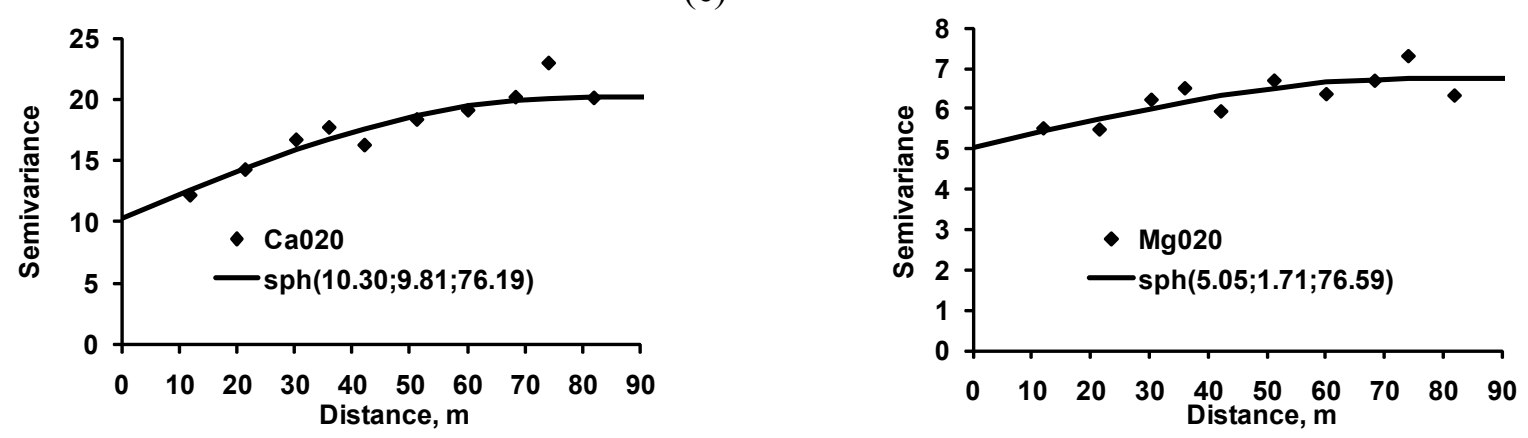

(f)

(g)
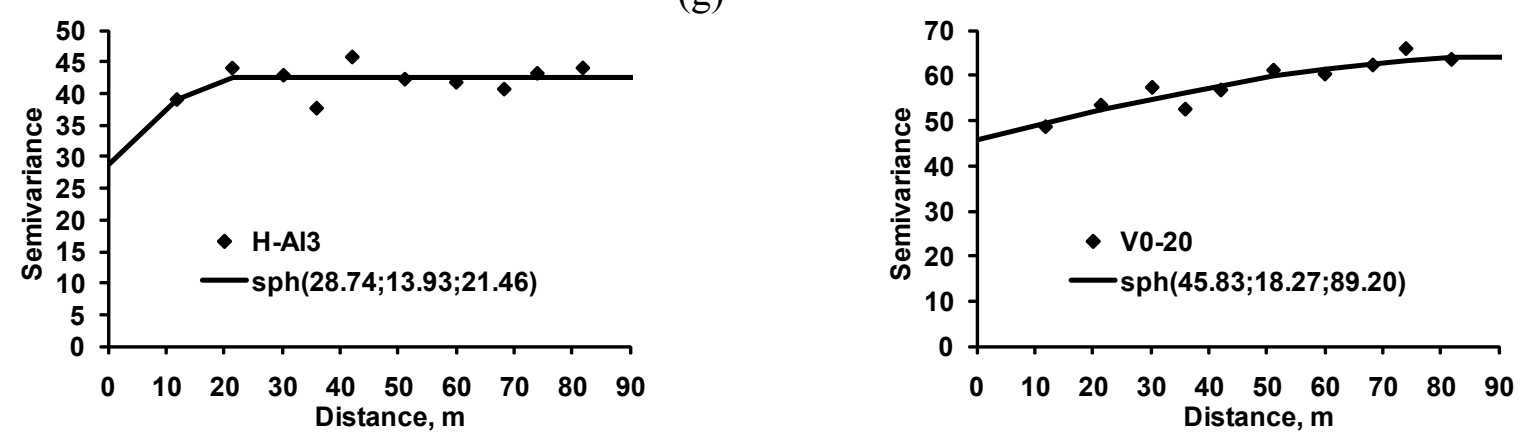

(h)

Figure 3. Semivariograms for soil chemical attributes 0.0 a $0.20 \mathrm{~m}$ of the depth: (a) $\mathrm{pH}$; (b) M.O.; (c) $\mathrm{P}$; (d) $\mathrm{K}^{+}$; (e) $\mathrm{Ca}^{2+}$; (f) $\mathrm{Mg}^{2+}$; (g) $\mathrm{H}+\mathrm{Al}^{3+}$; (h) V\%. 
(a)

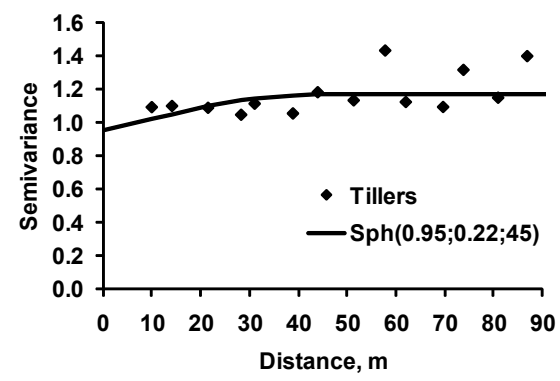

(d)

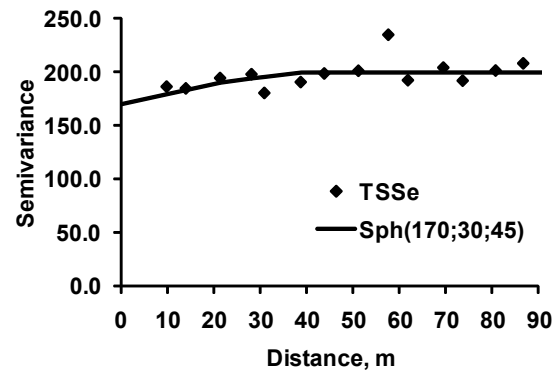

(b)

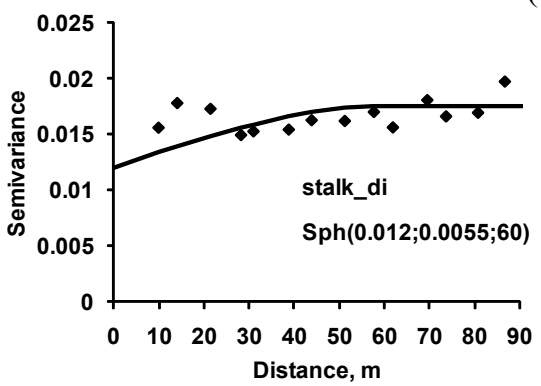

(e)

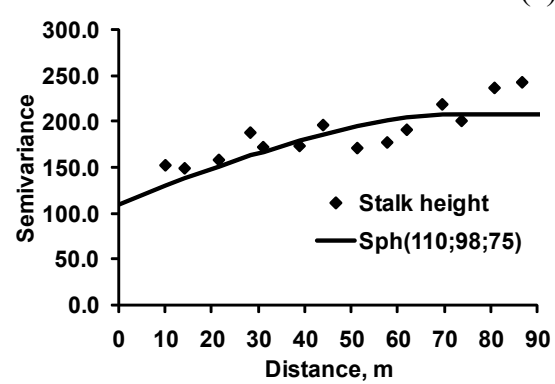

(c)

(f)

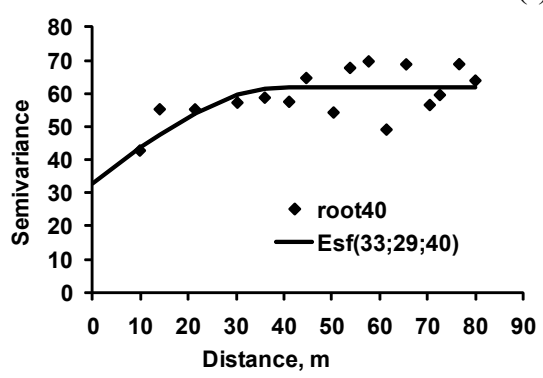

Figura 4. Semivariogram for biometric data of the sugar cane plant: (a) Tillers number; (b) Stalk diameter; (c) Stalk height; (d) TSSe; (e) Density of root 0-0.2 m; (f) Density of root 0.2-0.4 m.

Using descriptive statistics (Table 1) and semivariogram fitting parameters (Table 2) alone it can be said that it was practically impossible to find homogeneous sites to arrange plots in that area. This is an indication of the existence of patches in the area, and that the sampling distance applied represented spatial dependence, even in the smaller part of the area that was sampled using 97 points. This is in agreement with results by VIEIRA et al . (2008).

The isoline maps for the attributes in this study are presented in Figures 4, 5, 6, and 7. It can be noted that there is continuity across the diagonal direction of the area. There were patches in the maps (Figure 4) obtained by kriging for resistance to penetration values, with higher values in the upper right-hand corner of the area. This occurred especially at depths from 0.05 to $0.35 \mathrm{~m}$, as well as for number of strokes. The highest bulk density values were also found at that site and, when compared with maps for sugarcane plant attributes (Figure 7), it can be seen that smaller numbers of tillers, stalk diameter and height, productivity, and root density values at 0.20-0.40 $\mathrm{m}$ were obtained at the same site for the sugarcane plants. This indicates that soil compacted zones restricted plant development, which is in agreement with results by DiAS JUNIOR et al . (2005), and SEVERIANo et al. (2007).
With regard to soil chemical attributes at the 0.0-0.2 $\mathrm{m}$ depth, the inverse relation with physical attributes does not seem to occur as intensely as found for plant data because, in spite of the smaller contents of organic matter, magnesium, and hydrogen plus aluminum, higher $\mathrm{pH}$, potassium, calcium, and base saturation values were obtained in the area located in the upper right-hand corner. Results obtained by STAUT (2006) indicate that, regardless of texture, yield decreases from more fertile, eutrophic soils (high base saturation), to less fertile, alic soils (high aluminum saturation). Chemical attributes analyzed at greater depths than those presented in this work could more appropriately identify this relationship.

The large number of patches with different values in the maps illustrate the high variability of that field, indicating that the samplings were sufficient to characterize potential variability patches, especially because of the concentration obtained in the region where typical variability for resistance to penetration occurred, with better-defined patches.

\section{CONCLUSIONS}

1. The spatial variability found for soil attributes in the sugarcane production environment indicates that 
(a)
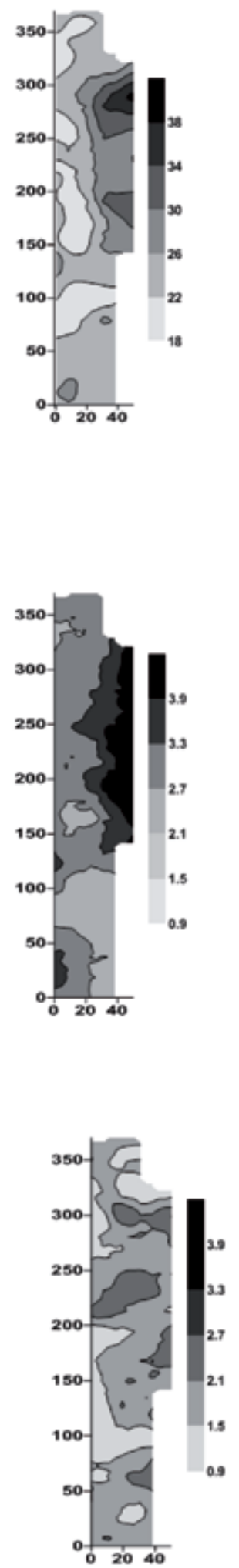

(e) (b)
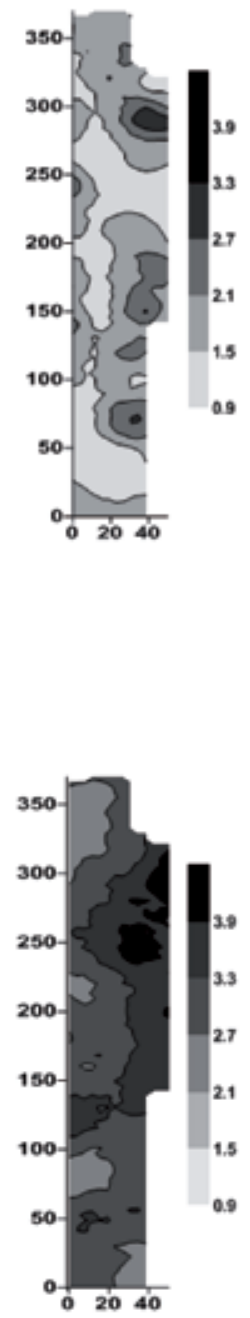

(i)

(f)

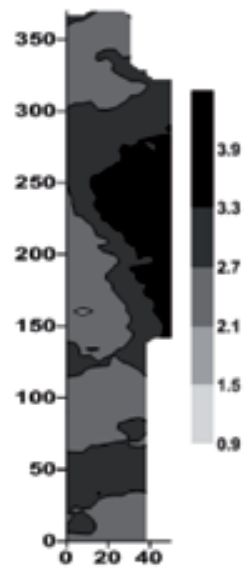

(j)

(c)

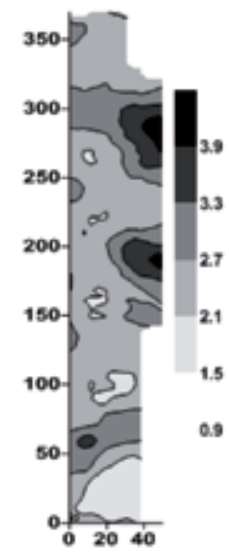

(g)

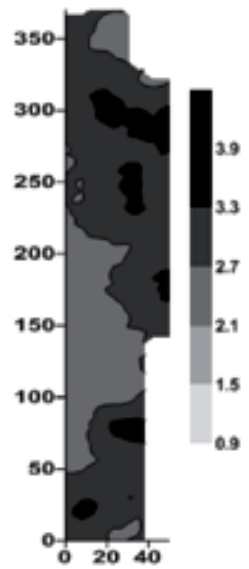

(k)
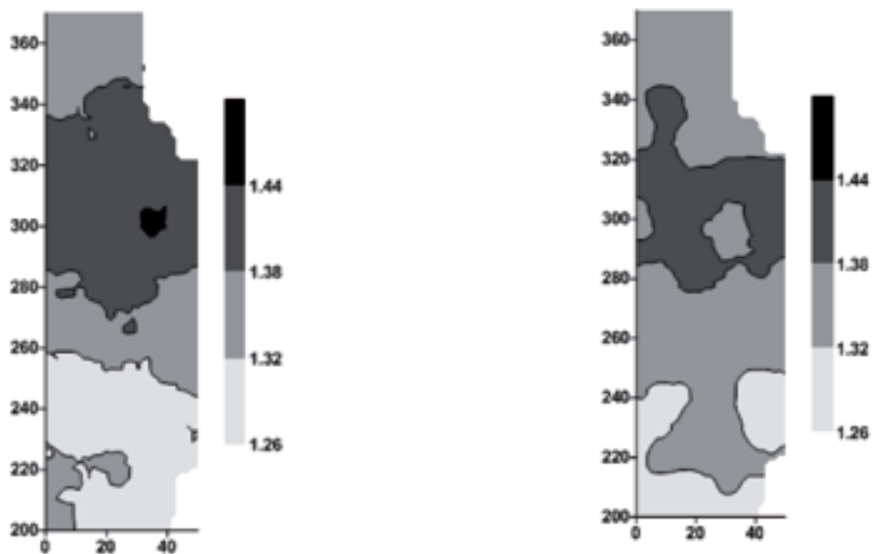

Figure 5. Maps for resistance penetration of soil 0.0-0.4 m depth: (a) Strokes of number; (b) Resistance kPa 0.0-0.05 m; (c) Resistance kPa 0.05-0.10 m; (d) Resistance kPa 0.10-0.15 m; (e) Resistance kPa 0.15-0.20 m; (f) Resistance kPa 0.20-0.25 m; (g) Resistance kPa 0.25-0.30 m; (h) Resistance kPa 0.30-0.35 m; (i) Resistance kPa 0.35-0.40 m. Maps for soil density (kg m³): (j) 0.0-0.20 m of the depth; (k) $0.20-0.40 \mathrm{~m}$ of the depth. 

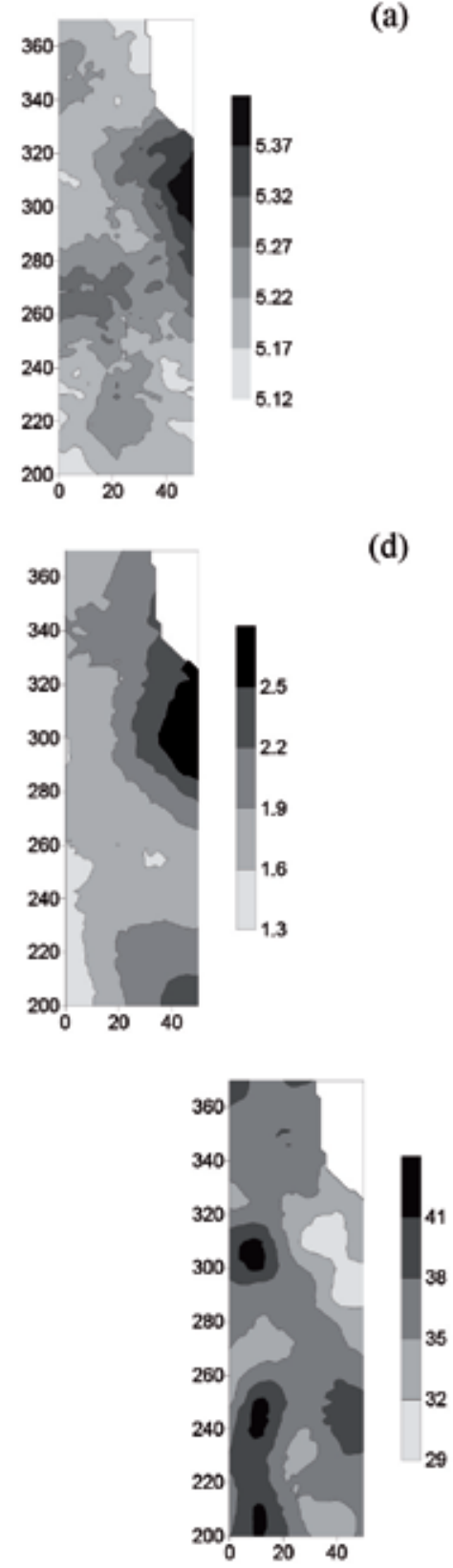

(d) (b)
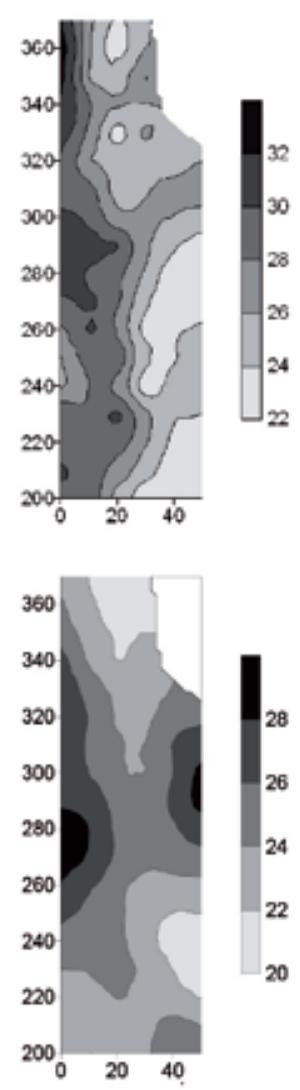

(g)

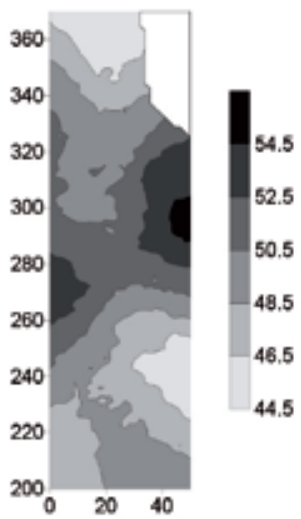

(c)

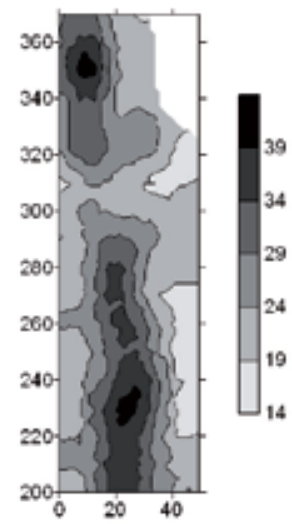

(f)

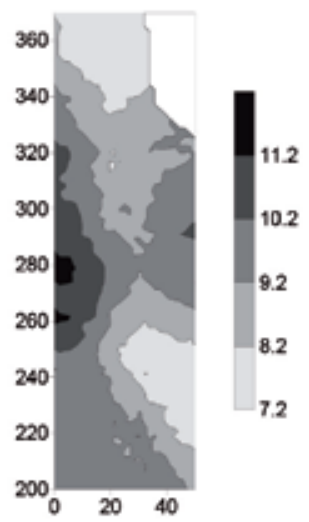

(h)

Figure 6 . Maps for soil chemical attributes 0.0-0.20 m of the depth: (a) $\mathrm{pH}$; (b) M.O.; (c) P; (d) $\mathrm{K}^{+}$; (e) $\mathrm{Ca}^{2+}$; (f) $\mathrm{Mg}^{2+}$; (g) $\mathrm{H}+\mathrm{Al}^{3+}$; (h) $\mathrm{V} \%$.

it is practically impossible to have homogeneous sites to arrange plots in the study area.

2. The samplings were sufficient to allow the characterization of potential variability patches, especially because better-defined patches were concentrated in the region where typical variability for resistance to penetration was obtained.

3. The adoption of geostatistical analysis contributed to increase the breeding effectiveness of sugarcane variety IACSP93-3046 at the clonal stage, helping the breeder to improve selection criteria, and can be also expanded into other areas and regions where variety trials are conducted.

\section{REFERENCES}

BALL-COELHO, B.; SAMPAIO, E.V.S.B.; TIESSEN, H.; STEWART, J.W.B. Root dynamic in plant ratoon crops of sugar cane. Plant and Soil, v.142, p.297-305, 1992. 
(a)

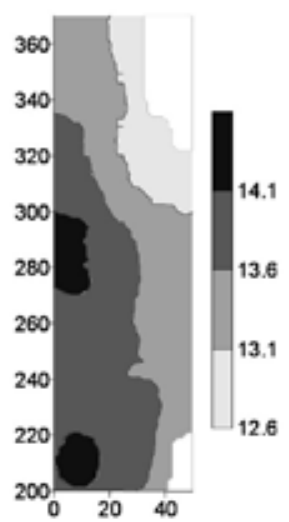

(d)

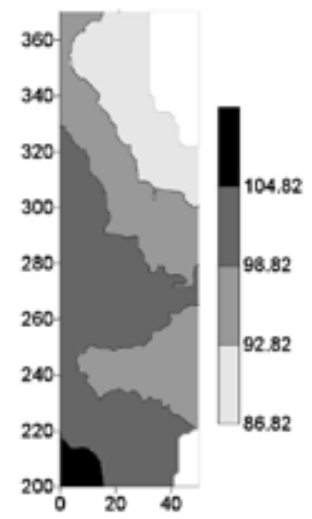

(b)

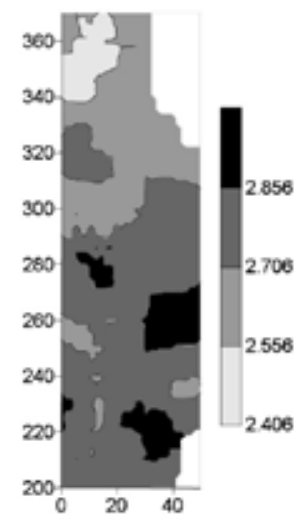

(e)

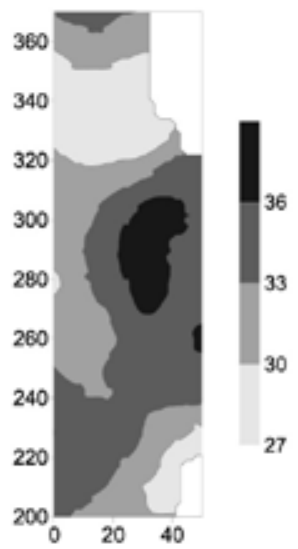

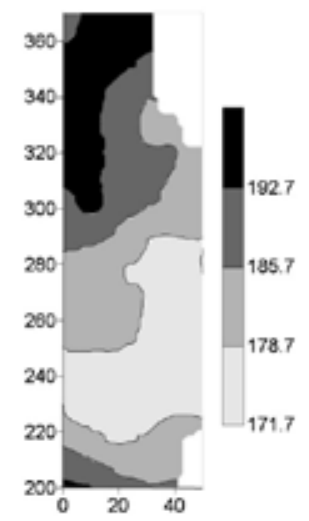

(f)

(c)

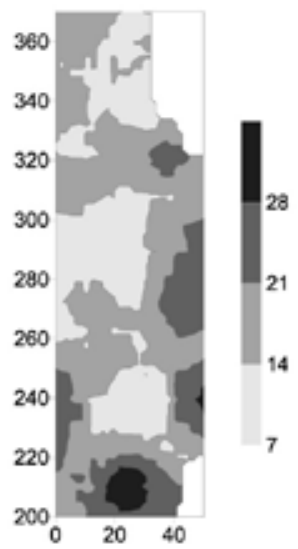

Figura 7. Maps for biometric data of the sugar cane plant: (a) Tillers number; (b) Stalk diameter; (c) Stalk height; (d) TSSe; (e) Density of $\operatorname{root}\left(\mathrm{kg} \mathrm{m}^{-3}\right)$ 0-0.2 $\mathrm{m}$; (f) Density of $\operatorname{root}\left(\mathrm{kg} \mathrm{m}^{-3}\right)$ 0.2-0.4 m.

BRADFORD, J.M. Penetrability. In: KLUTE, A. (Ed.). Methods of soil analysis: Physical and mineralogical methods. 2.ed. Madison: American Society of Agronomy, 1986, p.463-478.

CAMARGO, O.A.; MONIZ, A.C.; JORGE, L.A; VALADARES, J.M.A.S. Métodos de análise química, mineralógica e física de solos do Instituto Agronômico de Campinas. Campinas: Instituto Agronômico, 1986. 93p. (Boletim Técnico, 106)

CAMPBELL, J.B. Spatial variation of sand content and $\mathrm{pH}$ within single contiguous delineation of two soil mapping units. Soil Science Society of America Journal, v.42, p.460464, 1978.

CEDDIA, M.B.; ANJOS, L.H.C.; LIMA,E.; RAVELLI NETO, A.; SILVA, L.A. Sistemas de colheita de cana-de-açúcar e alterações nas propriedades físicas de um solo Podzólico Amarelo no Estado do Espírito Santo. Pesquisa Agropecuária Brasileira, v.34, p.1467-1473, 1999.

COUTO, E.G.; KLAMT, E.; STEIN, A. Variabilidade espacial de propriedades do solo influenciadas pela agricultura, em escala regional. In: MEIRELLES, M.S.P.; CAMARA, G.; ALMEIDA, C.M. (Eds.). Geomática, modelos e aplicações ambientais. Brasília: Embrapa Informação Tecnológica, 2007. p. $409-443$.

DIAS JUNIOR, M.S.; LEITE, F.P.; LASMAR JÚNIOR, E.; ARAÚJO JÚNIOR, C.F. Traffic effects on the soil preconsolidation pressure due to eucalyptus harvest operations. Scientia Agricola, v.62, p.248-255, 2005.

DINARDO-MIRANDA, L.L.; VASCONCELOS, A.C.M.; VIEIRA, S.R.; FRACASSO, J.V.; GREGO, C.R. Uso da geoestatística na avaliação da distribuição espacial de mahanarva fimbriolata em cana-de-açúcar, Bragantia, v.66, p.449-455, 2007.

EMBRAPA. Centro Nacional de Pesquisa de Solos. Sistema brasileiro de classificação de Solos. Brasília, 1999. 412p.

FARIAS, P.R.S.; BARBOSA, J.C.; BUSOLI, A.C. Distribuição espacial da lagarta-do-cartucho, Spodoptera frugiperda (J.E. Smith) (Lepidoptera: Noctuidae), na cultura do milho. Neotropical Entomology, v.30, p.681-689, 2001.

FARIAS, P.R.S.; ROBERTO, S.R.; LOPES, J.R.S.; PERECIN, D. Geostatitical characterization of the spatial distribution of 
Xylella fastidiosa sharpshooter vectors on citrus. Neotropical Entomology, v.33, p.13-20, 2004.

GOLDEN SOFTWARE - SURFER for windows. Release 7.0. Contouring and 3D surface mapping for scientist's engineers. User's guide. New York: Golden Software, 1999. 619p.

GOOVAERTS, P. Geostatistics for natural resources evaluation. New York: Oxford University Press, 1997. 476p.

GREGO, C.R.; VIEIRA, S.R.; ANTONIO, A.M.; ROSA, S.C.D. Geostatistical analysis for soil moisture content under the no tillage cropping system. Scientia Agricola, v.63, p.341-350, $2006 a$.

GREGO, C.R.; VIEIRA, S.R.; LOURENÇÃO, A.L. Spatial distribution of Pseudaletia sequax franclemlont in triticale under no-till management. Scientia Agricola, v.63, p.321-327, 2006b.

HORVAT, R.A.; XAVIER, M.A; GREGO, C.R.; VIEIRA, S.R. Avaliação da variabilidade espacial do número de perfilhos da cultura de cana-de-açúcar em relação à compactação do solo. In: CONGRESSO BRASILEIRO DE AGRICULTURA DE PRECISÃO, 2., 2006, São Pedro. Anais... Piracicaba: ESALQ/ USP, 2006. v.I. (CD-ROM)

LANDELL, M.G.A.; CAMPANA, M.P.; FIGUEIREDO, P.; VASCONCELOS, A.C.M.; BIDÓIA, M.A.P.; XAVIER, M.A.; DINARDO-MIRANDA, L.; PRADO, H.; ROSSETTO, R.; SANTOS, A.S.; PERECIN, D.; CAVICHIOLI, J.C.; MARTINS, A.L.M.; KANTHACK, R.A.D.; GALLO, P.B.; VEIGA FILHO, A.A.; SILVA, D.N.; ANJOS, I.A.; AZANIA, C.A M.; PINTO,L.R.; SOUZA, S.A.C.D. Variedades de cana-de-açúcar para o Centro-Sul do Brasil: 15. ${ }^{a}$ liberação do Programa Cana IAC (1959- 2005). Campinas: Instituto Agronômico, 2005. 33p. (Boletim técnico 197)

MACHADO, E.C. Fisiologia de produção de cana-de-açúcar In: PARANHOS, S.B. (Coord.). Cana-de-açúcar: cultivo e utilização. Campinas: Fundação Cargill, 1987. v.1, p.56-87.

MARTINS, A. L.M.; LANDELL, M. G.A. Conceitos e critérios para avaliação experimental em cana-de-açúcar utilizados no Programa: Cana IAC. Pindorama, Instituto Agronômico, 1995. p.15-20.

ORTIZ. J.O ; FELGUEIRAS, C.A ; DRUCK, Z. MONTEIRO, A M.V. Avaliação de procedimentos geoestatísticos de cokrigagem para determinação da distribuição espacial de propriedades de solos. In: MEIRELLES, M.S.P.; CAMARA, G.; ALMEIDA, C.M. (Ed.). Geomática: modelos e aplicações ambientais. Brasília: Embrapa Informação Tecnológica, 2007, p.387-408, 2007.

RAIJ, B. van; ANDRADE, J. C.; CANTARELLA, H.; QUAGGIO, J. A. Análise química para avaliação da fertilidade de solos tropicais. Campinas: Instituto Agronômico, 2001. 285p.

ROSOLEM, C.A.; FOLONI, J.S.S.; TIRITAN, C.S. Root growth and nutrient accumulation in cover crops as affected by soil compaction. Soil and Tillage Research, v.65, p.109-115, 2002.
ROSSETTO, R.; SPIRONELLO, A.; CANTARELLA, H.; QUAGGIO, J.A. Calagem para cana-de-açúcar e sua interação com doses de Potássio. Bragantia, v.63, p.105-119, 2004.

SEVERIANO, E.C.; OLIVEIRA, G. C.; DIAS JÚNIOR, M. S; CASTRO, M. B.; SOARES, R.A.B. Alterações estruturais em um Latossolo e um Cambissolo submetidos à colheita mecanizada da cana-de-açúcar. In: CONGRESSO BRASILEIRO DE CIÊNCIA DO SOLO, 31., 2007, Gramado. Anais... Porto Alegre: SBCS, 2007. v.1. (CD-ROM)

SILVA A M.; NAIME, J.M.;VAZ, C.M.P.; CRESTANA, S.;CRUVINEL, P.E. Tomografia computadorizada de raio $x$ gama para investigação não-evasiva. In: MARTIN NETO, L.; VAZ, C.M.P.; CRESTANA, S. (Ed.). Instrumentação avançada em ciência do solo. São Carlos: Embrapa Instrumentação Agropecuária, 2008. p.159-225.

SIQUEIRA, G. M.; MIGUEL, F. R. M.; GREGO, C. R.; XAVIER, M. A.; VASCONCELOS, A. C. M.; VIEIRA, S.R. Compactación del suelo y desarrollo de raíces de caña de azúcar (Saccharum officinarum L.). In: CONGRESSO ARGENTINO DE CIÊNCIA DO SOLO, 20., 2006, Salta-Jujuy. Anais... Salta-Jujuy: Madre Tierra, 2006. (CD-ROM)

SOUZA, Z. M.; MARQUES JUNIOR, J.; PEREIRA, G. T.; MOREIRA, L. F. Variabilidade espacial do $\mathrm{pH}, \mathrm{Ca}, \mathrm{Mg}$ e V\% do solo em diferentes formas do relevo sob cultivo de cana-deaçúcar. Ciência Rural, v.34, p.1763-1771, 2004.

STAUT, L.A. Condições dos solos para o cultivo de cana-deaçúcar. 2006. Artigo em Hypertexto. Disponível em: <http:/ / www.infobibos.com/Artigos / 2006_2/CanaSolo/index.htm >. Acesso em: 30 ago. 2007.

STOLF, R. Teoria e teste experimental de fórmulas de transformação dos dados de penetrômetro de impacto em resistência do solo. Revista Brasileira de Ciência do Solo, v.15, p.229-235, 1991.

TORMENA, C.A.; SILVA, A.P.; LIBARDI, P.L. Caracterização do intervalo hídrico ótimo de um Latossolo Roxo sob plantio direto. Revista Brasileira de Ciência do Solo, v.22, p.573-581, 1998.

VASCONCELOS, A.C.M. Desenvolvimento do sistema radicular e da parte aérea de socas de cana-de-açúcar sob dois sistemas de colheita: crua mecanizada e queimada manual. Jaboticabal, 2002. 140p. Tese (Doutorado) - Faculdade de Ciências Agrárias e Veterinárias, Universidade Estadual Paulista "Júlio de Mesquita Filho".

VASCONCELOS, A.C.M., CASAGRANDE, A.A. Fisiologia do sistema radicular. In: MIRANDA-DINARDO, L.L.; VASCONCELOS, A.C.M.; LANDELL, M.G.A (Eds.). Cana-deaçúcar. Campinas: Instituto Agronômico, 2008. p.79-97.

VIEIRA, S. R. Uso de geoestatística em estudos de variabilidade espacial de propriedades do solo. In: NOVAIS, R. F. (Ed.). Tópicos em Ciência do Solo 1. Viçosa: Sociedade Brasileira de Ciência do Solo, 2000. p.3-87. 
VIEIRA, S.R. Variabilidade espacial de argila, silte e atributos químicos em uma parcela experimental em um latossolo roxo de Campinas (SP). Bragantia, v.57, p.181-190, 1997.

VIEIRA, S.R.; MILLETE, J.A.; TOPP, G.C.; REYNOLDS, W.D. Handbook for Geostatistical analysis of variability in soil and meteorological parameters. In: ALVAREZ, V.H. (Ed.). Tópicos em Ciência do Solo 2. Viçosa: Sociedade Brasileira de Ciência do Solo, 2002. p.1-45,

VIEIRA, S.R.; XAVIER, M.A; GREGO, C.R. Aplicações de geoestatística em pesquisa com cana-de-açúcar. In: MIRANDADINARDO, L.L.; VASCONCELOS, A.C.M.; LANDELL, M.G.
A (Ed.). Cana-de-açúcar. Campinas: Instituto Agronômico. 2008. p.839-852.

WARRICK, A.W.; NIELSEN, D.R. Spatial variability of soil physical properties in the field. In: HILLEL, D.,(Ed.) Applications of soil physics. New York: Academic Press, 1980. p.319-344.

WEBSTER, R.; OLIVER, M.A. Geostatistics for environmental scientists. Chichester (England): John Wiley, 2001. 271p.

ZIMBACK, C.R.L. Análise especial de atributos químicos de solo para o mapeamento da fertilidade do solo. 2001. 114p. Tese (Livre Docência)-UNESP / FCA, Botucatu. 
